\title{
ANALYSIS OF ECONOMIC ON ENVIRONMENTAL DEGRADATION IN INDONESIA
}

\section{Rahardyan Haris Yuswinarto ${ }^{1}$ Edy Yusuf Agung Gunanto ${ }^{2}$}

\section{Article history:}

Submitted:

10 Juni 2021

Revised:

5 Juli 2021

Accepted:

12 Juli 2021

\section{Keywords:}

$A R D L$;

Economic growth;

Environmental pollution;

Population growth;

Transportation.

\section{Kata Kunci:}

ARDL;

Pertumbuhan ekonomi;

Pertumbuhan penduduk;

Polusi;

Transportasi.

\section{Koresponding:}

Diponegoro University, Central

Java, Indoensia

Email:

edyyusuffebundip@gmail.com

\section{Abstract}

Environmental degradation occurs is influenced by economic growth and the means of transportation that support it, besides that, the population size also affects the occurrence of environmental degradation. This study aims to determine the effect of economic growth, population growth and total of transportation on environmental degradation in short and long term. This research uses dynamic time series autoregressive distribution lag method. The results showed that the gross domestic product (GDP) variable had a significant positive effect in increasing $\mathrm{CO} 2$ gas emissions both in the short and long term. The variable amount of transportation has a positive and insignificant effect on the increase in $\mathrm{CO} 2$ gas emissions in the short term and has a negative effect in the long term. Meanwhile, population growth variable has a positive and significant effect in the short term and negative and significant in the long term.

\section{Abstrak}

Degradasi lingkungan terjadi di pengaruhi oleh pertumbuhan ekonomi dan sarana transportasi yang mendukungnya, selain itu jumlah populasi penduduk juga mempengaruhi terjadinya degradasi lingkungan. Penelitian ini bertujuan untuk mengetahui pengaruh pertumbuhan ekonomi, pertumbuhan penduduk dan jumlah transportasi terhadap degradasi lingkungan dalam jangka pendek dan jangka panjang. Penelitian ini menggunakan metode dynamic time series autoregressif distribution lag. Hasil penelitian menunjukan variabel produk domestik bruto (PDB) berpengaruh positif signifikan dalam peningkatan gas emisi $\mathrm{CO} 2$ baik jangka pendek maupaun jangka panjang. Variabel jumlah transportasi memiliki pengaruh positif tidak signifikan terhadap peningkatan gas emisi $\mathrm{CO} 2$ dalam jangka pendek dan memiliki pengaruh negatif dalam jangka panjang. Sementara variabel pertumbuhan jumlah penduduk memiliki pengaruh positif dan signifikan di jangka pendek dan negatif dan signifikan di jangka panjang.

Diponegoro University, Central Java, Indoensia

Email: rahardyan.haris.yuswinarto@gmail.com 
Analysis of Economic on Environmental Degradation...

Rahardyan Haris Yuswinarto \& Edy Yusuf Agung Gunanto

\section{INTRODUCTION}

The economy is an important thing that must be considered and developed in a country. This is because the economy is closely related to the survival of many people. However, on the other hand, along with economic development, a serious problem occurs, namely environmental degradation. The reduced sustainability of natural resources and the occurrence of pollution due to industry and deforestation into economic land are examples of the consequences of economic development followed by environmental degradation.

Munir \& Ameer (2018) explained that in general humans can develop without causing damage to the environment. It is known that during the last few years, great changes have taken place in the social and economic structure of the world. Humans and economic growth are closely related to environmental degradation as seen from the content of carbon dioxide (CO2) emissions in the air and manipulation of natural raw materials (United Nations Development Programme, 2015).

In recent years, research on the relationship between economic growth and environmental degradation has been carried out. Their research results show that economic growth that occurs in an area can cause systematic damage to natural resources and the environment. In addition, research in the world of health also explains that humans were seven times healthier one hundred years ago than we are today. Environmental conditions will continue to deteriorate if environmental degradation and economic growth have a linear relationship (AkbostancI et al., 2009).

The consequence of massive economic development is environmental climate change. Humans overexploitation of natural resources to extract fossil fuels to generate electricity by over-cutting forests (Ouahrani et al., 2011). This is done without considering the impact of development on environmental sustainability and the health of future generations. For example, the growth in world $\mathrm{CO} 2$ emissions from 17.78 billion tonnes in 1980 to 32.1 billion tonnes in 2015 and continues to increase (Bekhet \& Othman, 2017) and global warming which has had negative implications for human health, agriculture, economic activity and biodiversity and natural ecosystem functions. According to Stern (2008), if there is no treatment to reduce $\mathrm{CO} 2$ emissions in the air, then the level of greenhouse gases in the atmosphere will increase significantly in early 2035 and this is very dangerous for human health and survival.

Research by Alam et al., (2016) on economic growth and its impact on environmental degradation with case studies in Indonesia, India, China, and Brazil shows that these four countries are responsible for 34.9 percent of global $\mathrm{CO} 2$ emissions, with a proportion of the economic growth of these four countries in global GDP was 13.1 percent. These four countries accommodate 43.3 percent of the world's population. Other evidence shows that these countries managed to increase higher economic growth by changing their economies from the agricultural sector (pre-industrial) to an 
Analysis of Economic on Environmental Degradation...

Rahardyan Haris Yuswinarto \& Edy Yusuf Agung Gunanto

industrial sector that concentrates on the use of energy derived from natural resources.

Nasir \& Rehman (2011) explain that countries with a larger population are responsible for $\mathrm{CO} 2$ emissions. On the other hand, the level of $\mathrm{CO} 2$ emission in developing countries is higher than that of developed countries. Based on a study conducted by Alam et al., (2016) with research objects in four countries with the criteria of a population of more than 200 million in 2014 and the largest amount of $\mathrm{CO} 2$ emissions, the results show that population growth causes environmental degradation. According to the US Department of Energy's Center for Carbon Dioxide Information Analysis (CDIAC) 2010, among developing countries the largest CO2producing country is China (8286892t, with $6.195 \%$ of total global CO2 emissions) second place is India (2008823t, i.e. 5.98t. \% of total emissions), Indonesia is in the third position, namely (433989t, with a proportion of $1.29 \%$ of the total emission produced) while Brazil (419754t, i.e. $1.25 \%$ of total emissions). By population, the top developing countries are China (1356 million), India (1236 million), Indonesia (254 million) and Brazil (203 million).

Mikayilov et al., (2017) explained that the economic sector is closely related to transportation, because the benefits of transportation to the economy do not have a high value. Think of the economy as a living organism, the body's circulatory system is carried out by the transportation sector. Accelerating economic growth in developing countries aims at income growth, international trade growth, urbanization deposition, and which directly increases the need for transportation services. Transport services experienced demand during 2002 to 2020 should increase annual speeds by $3.6 \%$ in developing countries, and $1.5 \%$ in developed countries.

In addition to providing benefits to economic growth, the negative effects of quantity-growing transportation on ecosystems are also inevitable. The negative effects of transportation that must be considered are those related to the atmosphere, hydrosphere, biosphere, and others. The effect of transportation on the atmosphere depends on the level of development. certain types of transportation with certain fuels can have a devastating impact on the earth's atmosphere (Mikayilov et al., 2017).

Chandran \& Tang (2013) in their research on what factors influence $\mathrm{CO} 2$ gas emissions using a sectoral approach. In 2009, coal, oil, and agriculture accounted for $43 \%$, $36.7 \%$ and $20 \%$ of world $\mathrm{CO} 2$ emissions, respectively. Combustion of fossil fuels is a major contributor to $\mathrm{CO} 2$ emissions. Among these sectors, the transportation sector is the sector that contributes to $\mathrm{CO} 2$ emissions from burning vehicle fuels.

Countries with low wages are likely to experience environmental degradation, however, when they reach high levels of state income there will be a turning point that will cause the effect of environmental degradation to be reduced. This can be seen from the environmental kuznezt curve (EKC), the initial stage, namely the pre-industrial economy and the second stage, namely the industrial economy phase, which is marked 
Analysis of Economic on Environmental Degradation...

Rahardyan Haris Yuswinarto \& Edy Yusuf Agung Gunanto

by the economic transition from the agricultural sector to the industrial sector followed by an increase in emissions. After that the industrial sector shifts to the service sector in the third stage, namely the postindustrial economy. Therefore, this trend is accompanied by a decrease in environmental pollution along with an increase in income (Panayotou, 2000).

A recent study by Davalos (2016) on the relationship between aggregate income and carbon dioxide emissions reveals evidence of the occurrence of the EKC theory in the Dominican Republic. In addition, a study conducted by Ali et al., (2015) on environmental degradation carried out in developing countries with the aim of examining the short and long term relationship between $\mathrm{CO} 2$, energy consumption, and economic growth using the Johensen cointegration approach. The results of his research indicate a relationship in the long term but not in the short term. Various studies have applied the ARDL cointegration technique or the cointegration bound test developed by Pesaran et al., (2001) to examine the long and short term relationship between economic indicators and environmental indicators.

In a study conducted by Balaguer \& Cantavella (2016) using CO2 emissions as an environmental indicator and oil prices as an indicator of fuel energy consumption in Spain through ADRL, EKC is supported. Zambrano-Monserrate et al., (2016) investigated $\mathrm{CO} 2$ emissions, economic growth, and energy consumption using the ARDL approach to cointegration in Ecuador and Brazil. The empirical findings of both studies support the validity of the EKC.

Pao \& Tsai (2011) also demonstrated a U-shaped inverse relationship for $\mathrm{CO} 2$ emissions, energy consumption, and income in Brazil. Zambrano-Monserrate et al. (2016) also confirmed the existence of a long-term EKC in Iceland in a study conducted to determine the relationship between energy consumption, trade openness, GDP and CO2 emissions using ARDL-bound testing against cointegration. The EKC hypothesis is also supported in a study investigating energy consumption, GDP, trade openness and urbanization in Kenya using the ARDL approach (Al-Mulali et al., 2016). Causal linkages between economic growth, financial development, trade openness and $\mathrm{CO} 2$ emissions, as well as the presence of EKC were also observed in 40 European countries during the period $1-85$ to 2014.

In a study by Saboori \& Sulaiman (2013), the EKC hypothesis was also supported in the Association of Southeaster Asian Nations (ASEAN) countries because the cointegration relationship between carbon emissions, economic growth and energy consumption was found through the ARDL method and the Granger causality test based on the correction model. vector error (VECM). In another study, Saboori \& Sulaiman (2013) also found EKC for CO2 emissions and GDP for the long and short term in Malaysia. Alabdulrazag \& Alrajhi (2016) also found support for EKC in Saudi Arabia by using the ADRL method to determine the relationship between $\mathrm{CO} 2$ emissions of economic growth, energy consumption and population density. 
Analysis of Economic on Environmental Degradation...

Rahardyan Haris Yuswinarto \& Edy Yusuf Agung Gunanto

Based on some literature and supported by the environmental kuznezt curve theory described in the section above, it can be concluded that there are important things to worry about related to human activities related to economic growth and transportation as well as increasing population because it can produce greenhouse gas emissions which are excessive and has a negative impact on the environment. This study aims to determine the impact of economic growth, population growth and total transportation on the increase in $\mathrm{CO} 2$ gas emissions and to determine the impact of these emissions so that they can be used as monitoring and consideration for sustainable environmental management.

\section{RESEARCH METHODS}

The analysis model of this research uses a quantitative approach with the dynamic time series Autoregressive Distributed Lag (ARDL) method. This method was introduced by Pesaran et al., (2001) which is a regression model that produces a different response or relationship to the long and short term dependent variable on one unit change in explanatory value or the independent variable (Gujarati \& Porter, 2003).

Compared to the integration technique proposed by Engle \& Granger (1987); Johansen (1988); Johansen \& Juselius (1990) the ARDL method is a much better method. The cointegration method proposed by Engle \& Granger (1987) relates to the long-term effect given by all stationary variables at the same point, whereas the ARDL approach uses one type of rejection and all variables do not need to be stationary at the same time. The stationary level in the ARDL approach as an integration variable can be worth I (0), I (1), but the stationary level must not exceed the level of level 2 or I (2). In addition, for small and limited data, the ARDL method can be used (Pesaran et al., 2001).

In this study, the data source used was secondary data. Secondary data collection was obtained through the BP Energi Dunia website, the Central Bureau of Statistics and the World Bank website as well as some literature related to this research. The type of data used in this study is data in the form of time series over a period of several years from 1965 to 2019, including GDP, population growth, the number of motorized vehicles and data on carbon dioxide (CO2) emissions. The GDP used to show how economic growth affected environmental degradation. Population growth indicates consume rate of energy. The number of motorized vehicles is one of indicator caused carbon dioxide (CO2) increase.

The research model is written in the following formula:

$$
\begin{array}{r}
\Delta Y_{t}=\beta_{0}+\sum_{i=1}^{k} \beta_{1}{ }_{1} \Delta Y 1_{t-1}+\sum_{i=1}^{k} \beta_{2} \\
{ }_{2} \Delta X 1_{t-i+} \sum_{i=1}^{k} \beta_{3} \Delta X X_{t-i}+\sum_{i=1}^{k} \beta_{4} \Delta X^{3_{t-i}}+\theta_{1} \\
Y_{t-I}+\theta_{2} X 1_{t-I}+\theta_{3} X 2_{t-I}+\theta_{4} X 3_{t-I}+e_{t} \ldots \ldots \ldots(1)
\end{array}
$$

Information:

$\begin{array}{ll}\beta 0 & =\text { Constant } \\ \beta 1 \beta 2 \beta 3 \beta 4 & =\text { Short run coefficient, } \\ \Delta & =\text { First difference, } \\ \theta 1 \theta 2 \theta 3 \theta 4 & =\text { Long run coefficient, } \\ \mathrm{k} & =\text { Long lag, } \\ \mathrm{I} & =\text { Order lag dan } \\ \mathrm{e} \_\mathrm{t} & =\text { error term. }\end{array}$


Analysis of Economic on Environmental Degradation...

Rahardyan Haris Yuswinarto \& Edy Yusuf Agung Gunanto

The specification of the ARDL model in this study refers to the model owned by Helda et al., (2018) which uses the ARDL approach model to analyze research variables. In this study, the researcher included the variable $\mathrm{CO} 2$ gas emissions as the dependent variable and GDP, the percentage of population growth and the amount of transportation as the independent variables. So that researchers formulate the following model:

$$
\triangle C O 2_{t}=\beta_{0}+\sum_{i=1}^{k} \beta_{1}{ }_{1} C O 2_{t-i}+\sum_{i=1}^{k} \beta_{2}
$$

${ }_{2} \Delta$ PDB $_{t-i}+\sum_{i=1}^{k} \beta_{3}{ }_{3}{ }_{\text {Population }}$ Pop $i+\sum_{i=1}^{k} \beta_{4}$ ${ }_{4}$ Transport $_{t-i}+\theta_{1} C O 2_{t-I}+\theta_{2} P D B_{t-I}+$ $\theta_{3}$ Population $_{t-I}+\theta_{4}$ Transport $_{t-I}+e_{t} \ldots$...(2)

Information: $\boldsymbol{C O}_{t-i}=$ lag of $\mathrm{CO} 2$ gas in a million tons, $\boldsymbol{\triangle} \boldsymbol{P} \boldsymbol{D} \boldsymbol{B}_{t-i}=$ lag from GDP in units of the year, APopulation Pr-i $=$ lag of total population growth in percentage units, $\Delta_{\text {Transport }}{ }_{t-I}=$ lag of the amount of transport in the unit quantity.

The long-term influence on this research can be written:

$$
\Delta C O 2_{t}=\beta_{0}+\theta_{1} C O 2_{t-I}+\theta_{2} P D B_{t-I}+
$$
$\theta_{3}$ Population $_{t-I}+\theta_{4}$ Transport $_{t-I}+e_{t}$

While the short-term effect can be written:

$$
\triangle C O 2_{t}=\beta_{0}+\sum_{i=1}^{k} \beta_{1}{ }_{1} C^{C O 2} 2_{t-i}+\sum_{i=1}^{k} \beta_{2}
$$
${ }_{2} \Delta$ Industry ${ }_{t-i}+\sum_{i=1}^{k} \beta_{3}{ }_{3}$ Transport $_{t-i}+\delta E C_{t}$ $+e_{t}$

Information: $\delta$ is the coefficient of the error correction term which shows the speed at which the short-term to long-term balance is adjusted. This means that the lag imbalance in the previous year will be corrected for the long-term balance this year. According to
Salomo \& Hutabarat (2007) in order for the error correction model to be a valid model, co-integrated variables have a negative ECT value and are statistically significant.

\section{RESULT AND DISCUSSION}

Unit Roots Test Results. The first step in the ARDL model analysis is to test the stationary level of each variable used in the analysis. This step is carried out to determine with certainty that the data cannot be stationary at order I (2) or level diff 2 to avoid false regressions (Keho, 2015). According to Pesaran et al., (2001), the ARDL model in stationary level testing only applies if the variables are at level I (0) and diff 1 I (1). In this study, the stationarity test used was the Phillips Perron approach (Table 1).

Table 1.

Unit Root Test Result Phillips Perron

\begin{tabular}{cccc}
\hline Variable & PP & Prob. & Information \\
\hline CO2 & -3.129 & $0.031(5 \%)$ & $\mathrm{I}(1)$ \\
PDB & -4.349 & $0.001(1 \%)$ & $\mathrm{I}(1)$ \\
Transport & -2.658 & $0.088(10 \%)$ & $\mathrm{I}(1)$ \\
Population & -6.182 & $0.000(1 \%)$ & $\mathrm{I}(1)$ \\
\hline
\end{tabular}

Source: Data Processing Results, processed using Eviews 10 (2020)

Based on the results of the unit root test, the test results show that the variables of the amount of $\mathrm{CO} 2$, GDP, total transportation and the percentage of population growth are stationary at the order I level or written as I (1) with a significance level of 1-10 percent. Based on the results of this stationary test, it can be concluded that the variables have been integrated in the same order and did not reach 
Analysis of Economic on Environmental Degradation...

Rahardyan Haris Yuswinarto \& Edy Yusuf Agung Gunanto

order 2 so that this fulfills the requirements for using the ARDL model.

Optimal Lag Test Results (Lag Length Criteria). After it is known that the method suitable for this research is the ARDL model, the next step is to determine the optimal lag length. The optimal lag test is needed to explain how long the influence of a variable is on other variables.

Table 2.

Lag Length Test Results

\begin{tabular}{ccccc}
\hline Lag & LR & FPE & AIC & HQ \\
\hline 0 & NA & $6.23 \mathrm{e}+34$ & 91.46849 & 91.52708 \\
1 & 663.8210 & $3.37 \mathrm{e}+28$ & 77.03471 & 77.32767 \\
2 & 127.4550 & $2.71 \mathrm{e}+27$ & 74.50139 & 75.02872 \\
3 & 20.49562 & $3.05 \mathrm{e}+27$ & 74.58513 & 75.34683 \\
4 & $55.58885 *$ & $1.11 \mathrm{e}+27 *$ & $73.50104 *$ & $74.49711^{*}$ \\
\hline
\end{tabular}

Source: Data Processing Results, processed using Eviews 10 (2020)

Based on the optimal lag test, the determination of the lag length is seen from the highest number of stars from the sequential modified LR test statistic (LR) value, the final prediction error (FPE), the Akaike Information Criteria (AIC) and the Han-Quinn Information Criteria (HQ). The test results show that the optimal lag length is at lag 4 .

Table 3

Cointegration Test Result Cointegration Bound Test

\begin{tabular}{ccccc}
\hline & & & $\mathbf{I}(\mathbf{0})$ & $\mathbf{I}(\mathbf{1})$ \\
\hline F-stat & 28.632 & $10 \%$ & 2.37 & 3.2 \\
$\mathrm{~K}$ & 2 & $5 \%$ & 2.79 & 3.67 \\
& & $2.5 \%$ & 3.15 & 4.08 \\
& & $1 \%$ & 3.65 & 4.66 \\
\hline
\end{tabular}

Source: Data Processing Result, processed using Eviews 10 (2020)

Cointegration Bound Test Results. Cointegration Bound Test was carried out with the aim of knowing the long-term balance between the variables used in the study (Table 3 ). The cointegration test results show that the statistical F value (28.63220) is greater than the critical value of the upper limit of $10 \%$ (3.2). Thus, the hypothesis which states there is no cointegration is rejected and the alternative hypothesis is accepted, which means that there is a longterm stable cointegration relationship between the $\mathrm{CO} 2$ gas variables, GDP, transportation and population.

ARDL Estimation Results (Model Estimation). At this stage, it enters testing the main model, namely estimating the ARDL model. Model selection based on akaike information criterion shows the best ARDL (4.0.2.1) model as shown in the following Table 4.

Table 4.

ARDL Model Estimation Results

\begin{tabular}{lcccc}
\hline Variable & Coefficient & Std. Error & t-Statistic & Prob.* \\
\hline CO2(-1) & 0.678010 & 0.123474 & 5.491098 & 0.0000 \\
CO2(-2) & 0.220262 & 0.159101 & 1.384414 & 0.1743 \\
CO2(-3) & -0.334214 & 0.150964 & -2.213865 & 0.0329 \\
CO2(-4) & 0.539120 & 0.136809 & 3.940665 & 0.0003 \\
PDB & $1.94 \mathrm{E}-10$ & $3.29 \mathrm{E}-11$ & 5.904641 & 0.0000 \\
TRANSPORT & $-2.60 \mathrm{E}-06$ & $9.49 \mathrm{E}-07$ & -2.738139 & 0.0094 \\
TRANSPORT(-1) & $-2.92 \mathrm{E}-06$ & $9.93 \mathrm{E}-07$ & -2.939917 & 0.0056 \\
TRANSPORT(-2) & $4.07 \mathrm{E}-06$ & $6.02 \mathrm{E}-07$ & 6.763447 & 0.0000 \\
POPULATION & 23848.94 & 9430.005 & 2.529049 & 0.0157 \\
POPULATION(-1) & -24429.44 & 10504.75 & -2.325561 & 0.0255 \\
C & 24.72565 & 45.25404 & 0.546374 & 0.5880 \\
\hline R-squared & 0.998050 & & & \\
Adjusted R-squared & 0.997537 & & & \\
\hline
\end{tabular}

Source: Data Processing Result, processed using Eviews 10 (2020)

The results of the ARDL model analysis above show that the $\mathrm{CO} 2$ variable has dynamic changes from the current period to lag 4, the GDP variable is only dynamic in the current period, the transportation variable has dynamic changes to lag 2 and the 
Analysis of Economic on Environmental Degradation...

Rahardyan Haris Yuswinarto \& Edy Yusuf Agung Gunanto

percentage of population growth has dynamic changes to lag 1 .In addition, in the model It also has relatively high R-square and Adj Rsquared of 0.99 and 0.99 . The R-square value of 0.998848 means that as much as $99.8 \%$ of the variation in the $\mathrm{CO} 2$ variable can be explained by the independent variables of this study and this indicates that this model is good enough to be used as an analysis.

Long Term Estimates. In seeing how big the long-term influence between the variables of GDP, transportation and the percentage of population growth observed on $\mathrm{CO} 2$ gas emissions. The results of the estimation of the long-term effect can be seen in the Table 5.

Table 5. Long-Term Test Results

\begin{tabular}{lcccc}
\hline Variable & Coefficient & Std.Error & t-Statistic & Prob. \\
\hline PDB & $2.38 \mathrm{E}-10$ & $7.68 \mathrm{E}-11$ & 3.104998 & 0.0032 \\
TRANSPORT & $7.33 \mathrm{E}-07$ & $5.93 \mathrm{E}-07$ & 1.235082 & 0.2227 \\
POPULATION & -13922.86 & 1024.036 & -13.59606 & 0.0000 \\
\hline
\end{tabular}

Source: Data Processing Result, processed using Eviews 10 (2020)

The results of the long-term estimation calculation from the table above shows that in the long run the determining factor for environmental pollution $(\mathrm{CO} 2$ gas emissions) is GDP and the percentage of population growth seen from the estimated coefficient of GDP and the percentage of population growth has a greater and more significant value than the small coefficient and insignificant transportation.

Short Run Estimates of the ECM Model. The calculation of the estimation results in the short-term analysis in the ARDL model can be seen in the estimation results of the Error Correction Method (ECM) in Table 6 which shows that the population variable has a significant positive effect and the GDP variable has a positive and significant effect, while the transportation variable is negative and insignificant.

The estimation results of the ECMARDL model in the table 6. show that the Coint Eq coefficient is negative and significant at the 1 percent level, namely 0.0000. This indicates that the ECM model used in this study is valid. The CointEq coefficient means that the short-term deviation adjustment process occurs quite slowly. This adjustment is only about 23.7 percent annually. The speed of adjustment from the previous period's disequilibrium to its long-run equilibrium in the current period.

Table 6.

Short Term Effects Error Correction Model

\begin{tabular}{lcccc}
\hline \multicolumn{5}{l}{ Dependent Variable : D Log $($ CO2 $)$} \\
\hline Variable & Coefficient & SE & t-Statistic & Prob. \\
\hline D(PDB) & $1.25 \mathrm{E}-10$ & $3.30 \mathrm{E}-11$ & 3.7883067 & 0.0005 \\
D(TRANSPORT) & $-2.91 \mathrm{E}-07$ & $5.28 \mathrm{E}-07$ & -0.550052 & 0.5856 \\
D(POPULATION) & 0.000132 & $4.43 \mathrm{E}-05$ & 2.992601 & 0.0049 \\
CointEq(-1)* & -0.237844 & 0.032373 & -7.347008 & 0.0000 \\
\hline
\end{tabular}

Source: Data Processing Result, processed using Eviews 10 (2020)

The estimation results of the ECMARDL model in the table above show that the Coint Eq coefficient is negative and significant at the 1 percent level, namely 0.0000. This indicates that the ECM model used in this study is valid. The CointEq coefficient means that the short-term deviation adjustment process occurs quite slowly. This adjustment is only about 23.7 percent annually. The speed of adjustment 
Analysis of Economic on Environmental Degradation...

Rahardyan Haris Yuswinarto \& Edy Yusuf Agung Gunanto

from the previous period's disequilibrium to its long-run equilibrium in the current period.

Referring to the two tables above, it can be concluded that gross domestic product (GDP) has a positive and significant effect on $\mathrm{CO} 2$ gas emission variables in the short and long term. This result is different from the Environmental Kusnezt Curve theory. The positive effect of GDP in the short term is thought to be due to economic growth in developing countries such as Indonesia which still causes pollution or increases in $\mathrm{CO} 2$ gas and will increase every year.

Economic growth which continues to increase causes greater use of natural resources and also causes an increase in unwanted pollutants that can damage the environment. Economic growth will encourage an increase in population, increased demand for agricultural land, natural resources and water resources which will cause damage to forests, grasslands, fertile agricultural lands and environmental pollution and will increase the amount of CO2 (Abouie-Mehrizi et al., 2012). Meeting needs by producing more goods and services will require more $\mathrm{CO} 2$ emission production. The total population of Indonesia is estimated to increase by an average of $0.91 \%$ every year so that the total population in 2030 will reach 280.84 million people. On the other hand, the economic activities of the population still depend on the use of fossil energy with relatively wasteful energy use. Thus, $\mathrm{CO} 2$ emissions per population (tonnes/person) will grow from 1.67 tonnes/person in 2010 to 5.39 tonnes $\mathrm{CO} 2 /$ person for the base scenario in 2030 , or an increase of more than 3 times over the next 20 years ahead (Susanti, 2018).
According to Gebretsadik (2016), the problem of human population is a problem that underlies the problem of environmental damage, this is due to the large number of human populations on earth, so to solve the problem of environmental damage, it must first be limited to the number of population increases. Population growth is a major cause of socio-economic problems including environmental damage, pollution, desertification, deforestation, intensive planting, over use of grazing and other environmental problems (Reza, 2016).

According to Adams et al., (2020) population distribution and growth can determine whether transportation energy can have a negative or positive impact on the environment. This is because smaller populations increase travel time and lead to increased carbon dioxide emissions, while denser populations will have the opposite effect. At the same time, population density can also affect the rate of economic growth and technology adoption which will affect environmental quality (Wang et al., 2020).

The transportation sector has caused atmospheric pollution and damaged the environment. Most academic research reveals a link between transportation, $\mathrm{CO} 2$ emissions and economic growth. Based on this fact, transportation-related $\mathrm{CO} 2$ emissions have caused a lot of attention among researchers around the world due to their fast growth rate and the fact that carbon dioxide is a major greenhouse gas. Currently, the transportation sector accounts for nearly $13 \%$ of total global greenhouse gas emissions, of which carbon dioxide emissions are the largest share. (Ozkan et al., 2019). 
Analysis of Economic on Environmental Degradation... Rahardyan Haris Yuswinarto \& Edy Yusuf Agung Gunanto

Classical Assumption Test Results. Data validity tests or classical assumptions are carried out in order to show good results of data analysis and have a significant and real relationship. This test is conducted in relation to the assumptions of classical linear regression models such as normality, autocorrelation and heteroscedasticity.

Table 7.

Normality Test Results

\begin{tabular}{llll}
\hline \multicolumn{4}{l}{ Normality Test Jarque Bera } \\
\hline Jarque Bera & 5.5228 & Probability & 0.0632 \\
\hline
\end{tabular}

Source: Data Processing Result, processed using Eviews 10 (2020)

Table 8.

Auto Correlation Test Results

\begin{tabular}{lccc}
\hline $\begin{array}{l}\text { Durbin } \\
\text { Watson }\end{array}$ & & & \\
\hline Value DW & 1.994330 & Value dL & 1.440 \\
Information & $\begin{array}{c}\text { Not affected by } \\
\text { autocorrelation }\end{array}$ & Value dU & 1.678 \\
& & \\
\hline
\end{tabular}

Source: Data Processing Result, processed using Eviews 10 (2020)

Table 9.

Auto Hetereoskadistas Test Results

\begin{tabular}{llll}
\hline \multicolumn{4}{l}{ Heteroskedasticity Test: } \\
\hline F-statistic & 3.853622 & Prob. F(10,38) & 0.0012 \\
Obs*R- & 24.67165 & Prob.ChiSquare(10) & 0.0060 \\
squared & & & \\
\hline
\end{tabular}

Source: Data Processing Result, processed using Eviews 10 (2020)

The classical assumption test in the three tables above shows that this study passes the requirements of the normality, autocorrelation and heteresocadity test. So it can be concluded that the variable data used is normally distributed, there is no serial correlation and the residuals are homoscedastic.
Stability Test Results. Stability tests were performed to check the level of stability between long-term measurements and shortterm adjustments in the ECM-ARDL model. If the CUSUM statistical plot is within the critical limit at the 5 percent level then the null hypothesis all coefficients in the regression are stable (Figure 1).

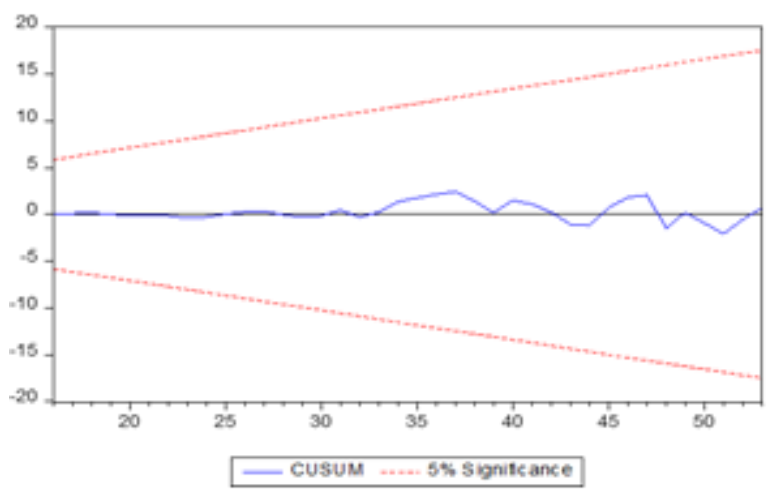

Source: Data Processing Result, processed using Eviews 10 (2020)

Figure 1.

Cumulative Sum (CUSUM) of Recursive Results

Figure 1 shows that the CUSUM plot is within the critical limit of 5 percent, which means that the short-term and long-term coefficients are stable in the Error Correction Method (ECM) -ARDL.

\section{CONCLUSION AND SUGGESTION}

There is a short-term and long-term relationship between the research variables. The gross domestic product (GDP) variable has positive and significant effect on the increase in $\mathrm{CO} 2$ gas emissions in the short and long term The variable amount of transportation has a positive and insignificant effect on the increase in $\mathrm{CO} 2$ gas emissions in 
Analysis of Economic on Environmental Degradation...

Rahardyan Haris Yuswinarto \& Edy Yusuf Agung Gunanto

the short and long term. Population growth variable has a positive and significant effect in the short term and negative and significant in the long term.

Policy makers and bureaucrats must pay attention to policies made in increasing economic growth, one of which is by paying attention to environmental conditions. Maximizing the AMDAL and land use that will be used for industrial or economic development. Policy makers and bureaucrats must pay attention to and control the growth in population numbers and distribution to reduce environmental degradation. The large number of people in an area will greatly affect the income, not carbon dioxide emissions. Transportation will continue to increase as the economy grows in a region, this is because transportation is a means of supporting economic growth. So the government should continue to make improvements related to fuel to be used for transportation to reduce air pollution. The weaknesses of this study is only used total amount of transportation variable that had direct impact to $\mathrm{CO} 2$ growth. Further research should be use more direct impact variables such as industry, investment and initial emissions of $\mathrm{CO} 2$ itself.

\section{REFERENCES}

Abouie-Mehrizi, M., Atashi, S. M., \& Elahi, M. (2012). The effect of variables population growth, urbanization and economic growth on $\mathrm{CO} 2$ Emissions in Iran. African Journal of Business Management, 6(288), 8414-8419. https://doi.org/10.5897/AJBM11.2020

Adams, S., Boateng, E., \& Acheampong, A. O. (2020). Transport energy consumption and environmental quality: Does urbanization matter? Science of The Total Environment, 744. https://doi.org/10.1016/j.scitotenv.2020. 140617

AkbostancI, E., Türüt-AsIk, S., \& Tunç, G. I. (2009). The relationship between income and environment in Turkey: Is there an environmental Kuznets curve? Energy Policy, Elsevier, 37(3), 861-867. https://ideas.repec.org/a/eee/enepol/v37y2009i 3p861-867.html

Al-Mulali, U., Solarin, S. A., \& Ozturk, I. (2016). Investigating The Presence of The Environmental Kuznets Curve (EKC) Hypothesis in Kenya: An Autoregressive Distributed Lag (ARDL) Approach. International Society for the Prevention and Mitigation of Natural Hazards, 80(3), 17291747. https://doi.org/10.1007/s11069-0152050-x

Alabdulrazag, B., \& Alrajhi, A. (2016). The Validity of Environmental Kuznets Curve Hypotheis in the Kingdom of Saudi Arabia: ARDL Bounds Testing Approach to Cointegration. International Review of Management and Business Research, 5(4), 1450-1464. https://www.researchgate.net/publication/339 130041_The_Validity_of_Environmental_Ku znets_Curve_Hypotheis_in_the_Kingdom_of _Saudi_Arabia_ARDL_Bounds_Testing_App roach_to_Cointegration

Alam, M. M., Murad, M. W., Noman, A. H. M., \& Ozturk, I. (2016). Relationships among carbon emissions, economic growth, energy consumption and population growth: Testing Environmental Kuznets Curve hypothesis for Brazil, China, India and Indonesia. Ecological Indicators, 70, 466-479. https://doi.org/10.1016/j.ecolind.2016.06.043

Ali, A., Khatoon, S., Ather, M., \& Akhtar, N. (2015). Modeling energy consumption, carbon emission and economic growth: empirical analysis for Pakistan. International Journal Energy Econpmic Policy, 5(2), 624-630. https://www.econjournals.com/index.php/ijee p/article/view/1011

Balaguer, J., \& Cantavella, M. (2016). Estimating the environmental Kuznets curve for Spain by considering fuel oil prices (1874-2011). Ecological Indicators, 60, 853-859. https://doi.org/10.1016/j.ecolind.2015.08.006

Bekhet, H. A., \& Othman, N. S. (2017). Impact of Urbanization Growth on Malaysia CO2 Emissions: Evidence from the Dynamic 
Analysis of Economic on Environmental Degradation...

Rahardyan Haris Yuswinarto \& Edy Yusuf Agung Gunanto

Relationship. Journal of Cleaner Production, 154, 374-388. https://doi.org/10.1016/j.jclepro.2017.03.174

Chandran, V. G. R., \& Tang, C. F. (2013). The impacts of transport energy consumption, foreign direct investment and income on $\mathrm{CO} 2$ emissions in ASEAN-5 economies. Renewable and Sustainable Energy Reviews, 24(C), $445-453$. https://doi.org/10.1016/j.rser.2013.03.054

Davalos, J. (2016). Sustainable economic growth: an empirical study for the aisa-pacific economic cooperation forum. International Journal Energy Economic Policy, 6(3), 594-601. https://www.econjournals.com/index.php/ijee p/article/view/2065

Engle, R. F., \& Granger, C. W. J. (1987). CoIntegration and Error Correction: Representation, Estimation, and Testing. Econometrica, 55(2), 251-276. https://doi.org/10.2307/1913236

Gebretsadik, T. (2016). Rapid population growth and Environmental degradation in Ethiopia: Challenges and Concerns. Journal of Ecology and The Natural Environment, 6(11), 32-40. https://core.ac.uk/download/pdf/234656401.p df

Gujarati, D. N., \& Porter, D. C. (2003). Basic econometrics (ed.). Newyork: McGrew Hill Book Co.

Helda, N. P., Jamal, A., \& Dawood, T. C. (2018). Pengaruh Urbanisasi, Pertumbuhan PDB SEKTOR Industri dan Pertumbuhan PDB Sektor Transportasi terhadap Polusi Lingkungan di Indonesia. Jurnal Ekonomi Dan Kebijakan Publik Indonesia, 5(2). 1-16. http://jurnal.unsyiah.ac.id/EKaPI/article/view/ $14212 / 0$

Johansen, S. (1988). Statistical Analysis of Cointegration Vectors. Journal of Economic Dynamics and Control, 12(2-3), 231-254. https://doi.org/https://doi.org/10.1016/01651889(88)90041-3

Johansen, S., \& Juselius, K. (1990). Maximum Likelihood Estimation and Inference on Cointegration - With Applications To the Demand for Money. Oxford Bulletin of Economics and Statistics, 52(2), 169-210. https://doi.org/https://doi.org/10.1111/j.14680084.1990.mp52002003.x

Keho, Y. (2015). An Econometric Study of the LongRun Determinants of $\mathrm{CO} 2$ Emissions in Cote 'Ivoire. Journal of Finance and Economics,
$3(2)$, 11-21. https://www.academia.edu/30488551/An_Eco nometric_Study_of_the_Long-

Run_Determinants_of_CO_2_Emissions_in_ Cote_dIvoire

Mikayilov, J., Shukurov, V., Mukhtarov, S., \& Yusifov, S. (2017). Does Urbanization Boost Pollution from Transport? Acta Universitatis Agriculturae et Silviculturae Mendelianae Brunensis, 65, 1709-1718. https://doi.org/10.11118/actaun201765051709

Munir, K., \& Ameer, A. (2018). Effect of economic growth, trade openness, urbanization, and technology on environment of Asian emerging economies. Management of Environmental Quality: An International Journal, 29(6), 1123-1134. https://mpra.ub.unimuenchen.de/id/eprint/74571

Nasir, M., \& Rehman, F. (2011). Environmental Kuznets Curve for Carbon Emissions in Pakistan: An Empirical Investigation. Energy Policy, 39(3), 1857-1865. http://www.sciencedirect.com/science/article/ pii/S0301-4215(11)00035-8

Ouahrani, A. El, Mesa, J. M., \& Merzouki, A. (2011). Anthropogenic $\mathrm{CO} 2$ emissions from fossil fuels Trends and drivers in the Mediterranean region. International Journal of Climate Change Strategies and Management, 3(1), 16-28. https://doi.org/10.1108/17568691111107925

Ozkan, T., Yangınlar, G., \& Kalayci, S. Y. (2019). Testing the Transportation-Induced Environmental Kuznets Curve Hypothesis: Evidence from Eight Developed and Developing Countries. International Journal of Energy Economics and Policy, 9(1), 174183. https://doi.org/10.32479/ijeep.7330

Panayotou, T. (2000). Economic Growth and the Environment. CID Working Paper Series. Cambridge: Harvard University.

Pao, H.-T., \& Tsai, C.-M. (2011). Modeling and forecasting the $\mathrm{CO} 2$ emissions, energy consumption, and economic growth in Brazil. Energy, Elsevier, 36(5), 2450-2458. https://doi.org/10.1016/j.energy.2011.01.032

Pesaran, M. H., Shin, Y., \& Smith, R. J. (2001). Bounds Testing Approaches to the Analysis of Level Relationships. Journal of Applied Econometrics, 16(3), 289-326. https://www.jstor.org/stable/2678547

Reza, S. (2016). Population Growth and 
Analysis of Economic on Environmental Degradation... Rahardyan Haris Yuswinarto \& Edy Yusuf Agung Gunanto

Environmental Degradation: The Case of Bangladesh Shishir. Available at: https://beabd.org/site/images/pdf/new17/97.pdf

Saboori, B., \& Sulaiman, J. (2013). CO2 emissions, energy consumption and economic growth in Association of Southeast Asian Nations (ASEAN) countries: A cointegration approach. Energy, 55(C), 813-822. https://doi.org/10.1016/j.energy.2013.04.038

Salomo, R., \& Hutabarat, P. M. (2007). Peranan Perdagangan Internasional Sebagai Salah Satu Sumber Pertumbuhan Ekonomi Indonesia. Seminar Pasca Sarjana Ilmu Ekonomi Universitas Indonesia.

Stern, N. (2008). The Economics of Climate Change. American Economic Review: Papers and Proceedings, 98(2), 1-37. https://doi.org/10.1257/aer.98.2.1

Susanti, E. D. (2018). Enviromental Kuznet Curve: Hubungan pertumbuhan Ekonomi Dengan Degradasi Kualitas Udara Dalam Pencapaian Millenium Development Goals (MDGs) Di Indonesia. (Skripsi). Yogyakarta: Universitas Negeri Yogyakarta.

United Nations Development Programme (UNDP). (2015). Human development report 2015: Work for human development. United States: PBM Graphics.

Wang, J., Hu, M., Tukker, A., \& Rodrigues, J. F. D. (2020). The impact of regional convergence in energy-intensive industries on China' s $\mathrm{CO} 2$ emissions and emission goals. Energy Economics, $\quad$ 80(2019), 512-523. https://doi.org/10.1016/j.eneco.2019.01.024

Zambrano-Monserrate, M. A., Valverde-Bajaña, I., Aguilar-Bohórquez, J., \& Mendoza-Jiménez, M. (2016). Relationship between economic growth and environmental degradation: Is there evidence of an environmental Kuznets curve for Brazil?. International Journal of Energy Economics and Policy, 6(2), 208-216. https://www.econjournals.com/index.php/ijee p/article/view/1850 